\title{
Thermodynamic Properties of Quinoxaline-1,4-Dioxide Derivatives: A Combined Experimental and Computational Study
}

\author{
Maria D. M. C. Ribeiro da Silva, ${ }^{,+}{ }^{\dagger}$ J osé R. B. Gomes, ${ }^{\dagger}$ J orge M. Gonçalves, ${ }^{\dagger}$ \\ Emanuel A. Sousa, ${ }^{\dagger}$ Siddharth Pandey, ${ }^{\ddagger}$ and William E. Acree, J $r .^{\ddagger}$ \\ Centro de Investi gação em Química, Departamento de Química, Faculdade de Ciências, \\ Universidade do Porto, Rua do Campo Alegre, 687, P-4169-007 Porto, Portugal, and \\ Department of Chemistry, University of N orth Texas, Denton, Texas 76203-5070 \\ mdsilva@f.up.pt
}

Received November 18, 2003

\begin{abstract}
The mean $(\mathrm{N}-\mathrm{O})$ bond dissociation enthal pies were derived for three 2-methyl-3-(R)-quinoxaline

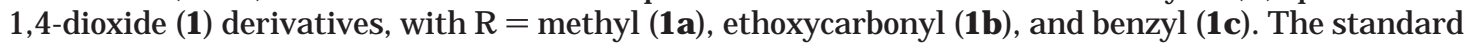
molar enthal pies of formation in the gaseous state at $T=298.15 \mathrm{~K}$ for the three $\mathbf{1}$ derivatives were determined from the enthalpies of combustion of the crystalline solids and their enthalpies of sublimation. In parallel, accurate density functional theory-based calculations were carried out in order to estimate the gas-phase enthalpies of formation for the corresponding quinoxaline derivatives. Also, theoretical calculations were used to obtain the first and second $\mathrm{N}-\mathrm{O}$ dissociation enthal pies. These dissociation enthal pies are in excel lent agreement with the experimental results herewith reported.
\end{abstract}

\section{Introduction}

The study of the molecular energetics of some classes of $\mathrm{N}$-oxide derivatives has been one of our interests over the past decade, ${ }^{1}$ with the main goal of using quantitative thermodynamic data for deriving the dissociation enthalpy of the nitrogen-oxygen dative covalent bond, $\mathrm{DH}_{\mathrm{m}}^{\mathrm{O}}(\mathrm{N}-\mathrm{O})$, which shows variation with its immediate molecular environment.

Compounds having the $\mathrm{N}$-oxide function, as other oxygenated species, can be ordered to establish a reactivity scale in terms of their abilities to transfer oxygen atoms in several biophysical chemistry conversions. ${ }^{2}$ Some aromatic heterocyclic di-N-oxides are thought to be required for selective biological activities, appearing to be very promising molecul es activated bioreductively as "hypoxic modifiers". ${ }^{3-6}$

* Phone: +351 226082838. Fax: +351 226082822.

† Universidade do Porto.

¥ University of North Texas.

(1) (a) Tucker, S. A.; Ribeiro da Silva, M. D. M. C.; Matos, M. A. R.; Goncalves, J. M.; Ribeiro da Silva, M. A. V.; Pilcher, G. J. Chem Thermodyn. 1995, 27, 391-398. (b) Acree, W. E., J r.; Powell, J . R.; Tucker, S. A.; Ribeiro da Silva, M. D. M. C.; Matos, M. A. R.; Gonçalves, J . M.; Santos, L. M. N. B. F.; Morais, V. M. F.; Pilcher, G. J . Org. Chem. 1997, 62, 3722-3726. (c) Ribeiro da Silva, M. D. M. C.; Matos, M. A. R.; Vaz, M. C.; Santos, L. M. N. B. F.; Pilcher, G.; Acree, W. E., J r.; Powell, J. R. J. Chem. Thermodyn. 1998, 30, 869-878. (d) Ribeiro da Silva, M. D. M. C.; Ferreira, S. C. C.; Rodrigues, I. A. P.; Silva, L. C. M.; Acree, W. E., J r.; Pandey, S.; R. L. E.J . Chem. Thermodyn. 2001, 33, 1227-1235. (e) Ribeiro da Silva, M. D. M. C.; Gonçalves, J. M.; Ferreira, S. C. C.; Silva, L. C. M.; Sottomayor, M. J .; Pilcher, G.; Acree E. E., J r.; Roy, L. E. J . Chem. Thermodyn. 2001, 33, 1263-1275. (f) Ribeiro da Silva, M. D. M. C.; Santos, L. M. N. B. F.; Silva, A. L. R.; Fernandes, O.; Acree, W. E. J., J r. J . Chem. Thermodyn. 2003, 35, $1093-1100$

(2) Holm, R. H.; Donahue, J. P. Polyhedron 1993, 12, 571-589.

(3) Skálová, L.; Nobilis, M.; Szotáková, B.; Wsól, V.; Kubícek, V.; Baliharová, V.; Kvasnicková, E. J . Chemi co-Biological Interactions 2000, 126, 185-200.
The oxygenation status of clonogenic cells in solid tumors is believed to be one of the major factors affecting tumor response to radiotherapy. There is evidence that the presence of hypoxia in human tumors influences the treatment of the malignancy, and some studies suggest that hypoxic cells may also be refractory to certain chemotherapeutic drugs. The concept of bioreductive activation of drugs in hypoxic cells to produce a more toxic compound has been extensively reviewed, and one of the general classes of such agents are 1,2,4-benzotriazine 1,4-di-N-oxide derivatives. ${ }^{7,8}$ The importance of the $\mathrm{N}$-oxide groups for the selective activity suggested the possibility of designing new heterocyclic $\mathrm{N}, \mathrm{N}$-dioxides and exploring their activity in hypoxic cells. It is also suggested that the more negative the reduction potential, the greater the hypoxic sel ectivity to the point at which enzymes can no longer reduce the compound.

In this context, the design and formation of $\mathrm{N}$-oxide derivatives, $5,9,10$ particularly quinoxaline $1,4-\mathrm{di}-\mathrm{N}$-oxide derivatives, have been attracting interest for important

(4) Greer, M. L.; Duncan, J . R.; Duff, J . L.; Blackstock, S. C. Tetrahedron Lett. 1997, 38, 7665-7668.

(5) Ortega, M. A.; Morancho, M. J .; Martínez-Crespo, F. J .; Sainz, Y.; Montoya, M. E.; Ceráin, A. L.; Monge, A. Eur. J . Med. Chem. 2000, $35,21-30$.

(6) Ganley, B.; Chowdhury, G.; Bhansali, J .; Daniels, J . D.; Gates, K. S. Bioinorg. Med. Chem. 2001, 9, 2395-2401.

(7) Monge, A.; Palop, J . A.; Ceráin, A. L.; Denador, V.; MartinezCrespo, F. J .; Sainz, Y.; Narro, S.; Garcia, E.; Miguel, C.; Gonzalez, M.; Hamilton, E.; Barker, A. J .; Clarke, E. D.; Greenhow, D. T. J . Med. Chem. 1995, 38, 1786-1792.

(8) Lin, A. J.; Cosby, L. A.; Sartorelli, A. C. J . Med. Chem. 1972, $15,1247-1252$.

(9) Boiani, M.; Cerecetto, H.; Gonzalez, M.; Risso, M.; Olea-Azar C.; Piro, O. E.; Castellano, E. E.; Ceráin, A. L.; Ezpeleta, O.; MongeVega, A. Eur. J. Med. Chem. 2001, 36, 771-782.

(10) Nagasawa, H.; Yamashita, M.; Mikamo, N.; Shimamura, M.; Oka, S.; Uto, Y.; Hori, H. Comp. Biochem. Phys. A 2002, 132, 33-40. 
pharmacological applications, as they have proved to be efficient cytotoxic agents for hypoxic cells of solid tumors. Accordingly, the knowledge of the energetics of the $\mathrm{N}-\mathrm{O}$ bonds in this class of compounds has a fundamental interest for the characterization of the behavior of the species, and this implies that study of this kind of molecules has to be expanded.

In previous work, ${ }^{1 b}$ we have determined the mean molar dissociation enthalpy of the $(\mathrm{N}-\mathrm{O})$ bonds, $\left\langle\mathrm{DH}_{\mathrm{m}}^{\mathrm{O}}(\mathrm{N}-\mathrm{O})\right.$, for some quinoxaline 1,4-dioxides, but the results are scarce, since quinoxaline derivatives are difficult to obtain in sufficiently pure conditions for thermochemical measurements. The present work reports experimental results that allow the derivation of the values of the standard molar enthalpies of formation, in the gaseous state, for three new $\mathbf{1}$ derivatives: $\mathbf{1 a}, \mathbf{l b}$, and 1c. To derive the values for $\left\langle\mathrm{DH}_{\mathrm{m}}^{\mathrm{O}}(\mathrm{N}-\mathrm{O})\right\rangle$, the gaseous enthalpies of formation of the corresponding quinoxaline derivatives without $(\mathrm{N}-\mathrm{O})$ bonds are re quired, although in the literature the experimental value is available for only one of the compounds: $\mathbf{2 a}$. $^{11}$ As for $\mathbf{2 b}$ and $\mathbf{2 c}$, it has not been possible to obtain samples with purity sufficient for calorimetric measurements; however, this problem has been overcome by estimating the values for their gas-phase enthalpies of formation, using accurate density functional theory calculations. These data, calculated with a good support for comparison between theory and experiment, are used to derive the correspondent $\left\langle\mathrm{DH}_{\mathrm{m}}^{\mathrm{O}}(\mathrm{N}-\mathrm{O})\right\rangle$ values.

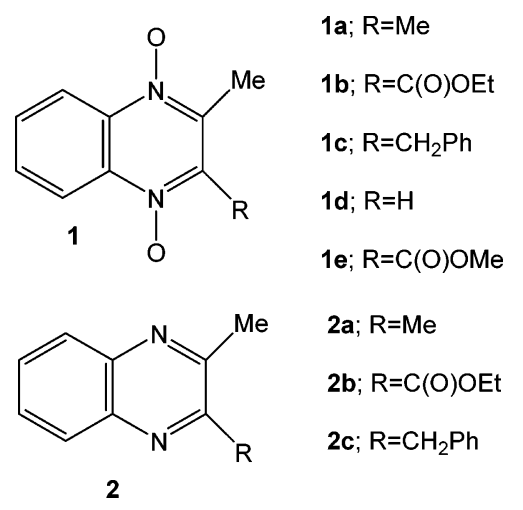

\section{Results}

Combustion. Results for a typical combustion experiment on each compound are given in Table $1 ; \Delta \mathrm{m}\left(\mathrm{H}_{2} \mathrm{O}\right)$ is the deviation of the mass of water added to the cal orimeter from $2900.0 \mathrm{~g}$, the mass assigned for $\epsilon$ (calor); $\Delta \mathrm{U}_{\Sigma}$ is the correction to the standard state; the remaining terms are as previously described. ${ }^{12}$ As samples were ignited at $\mathrm{T}=298.15 \mathrm{~K}, \Delta \mathrm{U}(\mathrm{IBP})=-\left\{\epsilon\right.$ (calor) $+\mathrm{c}_{\mathrm{p}}\left(\mathrm{H}_{2} \mathrm{O}\right.$ (I)) $\left.\cdot \Delta \mathrm{m}\left(\mathrm{H}_{2} \mathrm{O}\right)+\epsilon_{\mathrm{f}}\right\} \Delta \mathrm{T}_{\mathrm{ad}}+\Delta \mathrm{U}$ (ign); where $\Delta \mathrm{T}_{\mathrm{ad}}$ is the calorimeter temperature change corrected for heat exchange and the work of stirring. For the three dioxide derivatives considered in the present work, the individual values of $-\Delta_{\mathrm{c}} \mathrm{u}^{\mathrm{O}}$, together with the mean and its standard deviation, are given in Table 2. Table 3 lists the derived

(11) Ribeiro da Silva, M. A. V.; Morais, V. M. F.; Matos, M. A. R.; Rio, C. M. A.; Piedade, C. M. G. S. Struct. Chem. 1996, 7, 329-336. (12) Hubbard, W. N.; Scott, D. W.; Waddington, G. In Experimental Thermochemistry; Rossini, F. D., Ed.; Interscience: New York, 1956: Vol. 1, Chapter 5.
TABLE 1. Typical Combustion Experiments for Derivatives of 1 , at $T=298.15 K$

\begin{tabular}{|c|c|c|c|}
\hline & 1a & $\mathbf{1 b}$ & 1c \\
\hline $\mathrm{m}\left(\mathrm{CO}_{2}\right) / \mathrm{g}$ & 1.67790 & 1.71223 & 1.36497 \\
\hline $\mathrm{m}^{\prime}($ compound $) / \mathrm{g}^{\mathrm{a}}$ & 0.72314 & 0.80233 & 0.37591 \\
\hline $\mathrm{m}^{\prime \prime}(\mathrm{n}$-hexadecane $) / \mathrm{g}$ & & & 0.11744 \\
\hline $\mathrm{m}^{\prime \prime \prime}($ fuse $) / \mathrm{g}$ & 0.00306 & 0.00327 & 0.00358 \\
\hline$\Delta T_{a d} / K$ & 1.32261 & 1.27864 & 1.12302 \\
\hline$\epsilon_{f} /(J / K)$ & 15.66 & 15.81 & 15.65 \\
\hline$\Delta \mathrm{m}\left(\mathrm{H}_{2} \mathrm{O}\right) / \mathrm{g}$ & 0.8 & 0.7 & 0.5 \\
\hline$-\Delta U(I B P) / J^{b}$ & 20593.91 & 19908.92 & 17484.74 \\
\hline$\left.\Delta \mathrm{U}\left(\mathrm{HNO}_{3}\right) /\right]$ & 48.05 & 38.85 & 24.87 \\
\hline$\Delta \mathrm{U}($ carbon $) / \mathrm{J}$ & 2.64 & & \\
\hline$\Delta U($ ign $) / J$ & 0.98 & 1.08 & 1.10 \\
\hline$\Delta U_{\Sigma} / J$ & 14.33 & 15.24 & 9.06 \\
\hline$\Delta \mathrm{U}$ (n-hexadecane)/] & & & 5538.76 \\
\hline$\Delta U$ (fuse)/J & 49.69 & 53.10 & 58.14 \\
\hline$-\Delta_{c} u^{0} /(\mathrm{J} / \mathrm{g})$ & 28325.66 & 24678.80 & 31530.77 \\
\hline
\end{tabular}

TABLE 2. Individual Values of the Massic Energy of Combustion, $\Delta_{c} \mathbf{u}^{0}$, of Derivatives of 1 , at $T=298.15 \mathrm{~K}$

\begin{tabular}{ccc}
\hline \multicolumn{3}{c}{$-\Delta_{\mathrm{c}} \mathrm{u}^{0}(\mathrm{~J} / \mathrm{g})$} \\
\hline $\mathbf{1 a}$ & $\mathbf{1 b}$ & $\mathbf{1 c}$ \\
\hline 28314.35 & 24678.77 & 31548.63 \\
28314.39 & 24662.31 & 31501.25 \\
28359.67 & 24665.73 & 31562.45 \\
28316.61 & 24688.30 & 31512.78 \\
28325.66 & 24678.80 & 31507.80 \\
28316.18 & 24695.90 & 31530.77 \\
28351.94 & & 31550.40 \\
& & \\
$28328.4 \pm 7.3$ & $24678.3 \pm 5.2$ & $31528.3 \pm 8.2$ \\
a Mean value and standard deviation of the mean.
\end{tabular}

TABLE 3. Derived Standard $\left(p^{\circ}=0.1 \mathrm{MPa}\right)$ Molar Energies of Combustion, $\Delta_{\mathrm{c}} \mathbf{U}_{\mathrm{m}}^{\circ}$, Standard Molar Enthalpies of Combustion, $\Delta_{\mathrm{c}} \mathrm{H}_{\mathrm{m}}^{\circ}$, and Standard Molar Enthalpies of Formation, $\Delta_{\mathrm{f}} \mathrm{H}_{\mathrm{m}}^{\circ}(\mathrm{cr})$, in Crystalline State for Derivatives of 1 , at $T=298.15 \mathrm{~K}^{\mathrm{a}}$

\begin{tabular}{cccr}
\hline & $-\Delta_{\mathrm{c}} \mathrm{U}_{\mathrm{m}}{ }^{\circ}(\mathrm{cr})$ & $-\Delta_{\mathrm{c}} \mathrm{H}_{\mathrm{m}}{ }^{\circ}(\mathrm{cr})$ & \multicolumn{1}{c}{$\Delta_{\mathrm{f}} \mathrm{H}_{\mathrm{m}}{ }^{\circ}(\mathrm{cr})$} \\
\hline la & $5388.0 \pm 3.4$ & $5389.3 \pm 3.4$ & $25.0 \pm 3.6$ \\
1b & $6125.7 \pm 3.4$ & $6125.7 \pm 3.4$ & $-311.4 \pm 3.7$ \\
1c & $8395.8 \pm 5.4$ & $8399.5 \pm 5.4$ & $102.6 \pm 5.8$
\end{tabular}

${ }^{\text {a }}$ All values are given in $\mathrm{kJ} / \mathrm{mol}$.

standard molar enthalpies of combustion and of formation for these compounds. In accordance with normal thermochemi cal practice, ${ }^{13}$ the uncertainties assi gned to the standard molar enthalpies of combustion and formation are twice the overall standard deviation of the mean and include the uncertainties in calibration and in the auxiliary quantities used. To derive $\Delta_{\mathrm{f}} \mathrm{H}_{\mathrm{m}}^{\mathrm{O}}$ from $\Delta_{\mathrm{c}} \mathrm{H}_{\mathrm{m}}^{\mathrm{O}}$ of crystalline samples, the standard molar enthalpies of formation for $\mathrm{H}_{2} \mathrm{O}(\mathrm{l})(-285.83 \pm 0.04 \mathrm{~kJ} / \mathrm{mol})$ and for $\mathrm{CO}_{2}(\mathrm{~g})(-393.51 \pm 0.13 \mathrm{~kJ} / \mathrm{mol})$ were used. ${ }^{14}$

Sublimation. The results for the enthalpies of sublimation of $\mathbf{1 a}$ and $\mathbf{1 b}$, as determined by Calvet microcalorimetry, are $121.0 \pm 4.8$ and $130.6 \pm 1.2 \mathrm{~kJ} / \mathrm{mol}$,

(13) Olofsson, G. In Combustion Calorimetry; Sunner, S., Mansson, M., Eds.; Pergamon Press: New York, 1979; Vol. 1, Chapter 6.

(14) Cox, J. D.; Wagman, D. D.; Medvedev, V. A. CODATA Key Values for Thermodynamics; Hemisphere: New York, 1989. 
TABLE 4. Standard Molar Enthalpies of Sublimation, $\Delta_{\mathrm{cr}}^{\mathrm{g}} \mathbf{H}_{\mathrm{m}}^{\mathrm{o}}$, and Standard Molar Enthalpies of Formation, $\Delta_{\mathrm{f}} \mathrm{H}_{\mathrm{m}}^{\circ}$, for Quinoxaline-1,4-dioxide Derivatives, at $\mathrm{T}=$ $298.15 \mathrm{~K}^{\mathrm{a}}$

\begin{tabular}{rrrr}
\hline & \multicolumn{1}{c}{$\Delta_{\mathrm{f}} \mathrm{H}_{\mathrm{m}}^{\mathrm{O}}(\mathrm{cr})$} & \multicolumn{1}{c}{$\Delta_{\mathrm{cr}}^{\mathrm{g}} \mathrm{H}_{\mathrm{m}}^{\mathrm{O}}$} & \multicolumn{1}{c}{$\Delta_{\mathrm{f}} \mathrm{H}_{\mathrm{m}}^{\circ}(\mathrm{g})$} \\
\hline $\mathbf{1 a}$ & $25.0 \pm 3.6$ & $124.4 \pm 2.7$ & $149.4 \pm 4.5$ \\
$\mathbf{1 b}$ & $-311.4 \pm 3.7$ & $133.4 \pm 2.1$ & $-178.0 \pm 4.3$ \\
$\mathbf{1 c}$ & $102.6 \pm 5.8$ & $146.6 \pm 3.2$ & $249.2 \pm 6.6$
\end{tabular}

a All values are given in $\mathrm{kJ} / \mathrm{mol}$.

respectively, in reasonable agreement with those measured using the Knudsen effusion technique, listed in Tables S1 and S2 (given in Supporting I nformation). For 1c, the results were not reliable, and it has not been possible to obtain a confident value using this calorimetric technique.

The results for the measurement of the standard molar enthalpies of sublimation of $\mathbf{1 a}, \mathbf{1} \mathbf{b}$ and $\mathbf{1 c}$, determined using the Knudsen method, are summarized in Tables S1-S3 (Supporting I nformation), respectively, together with the mean temperatures of the experimental ranges and the standard molar enthalpies of sublimation at these mean temperatures, $\Delta_{\mathrm{cr}}^{\mathrm{g}} \mathrm{H}_{\mathrm{m}}^{\mathrm{O}}(<\mathrm{T}>)$; the parameter of the Clausius-Clapeyron equation corresponding to the slope was obtained using a least-squares fitting of the experimental data. The value of $\Delta_{c r}^{g} H_{m}^{O}(<T>)$ was corrected to $\mathrm{T}=298.15 \mathrm{~K}$ assuming $\Delta_{\mathrm{c}}^{\mathrm{g}} \mathrm{C}_{\mathrm{p}, \mathrm{m}}^{\mathrm{O}}=-50 \mathrm{~J} \mathrm{~K} \mathrm{~K}^{-1}$ $\mathrm{mol}^{-1}, 15$ yielding final values of $\Delta_{\mathrm{cr}}^{\mathrm{g}} \mathrm{H}_{\mathrm{m}}^{\mathrm{O}}$ for $\mathbf{l a}=124.4 \pm$ $2.7 \mathrm{~kJ} \mathrm{~mol}^{-1}, \mathbf{1 b}=133.4 \pm 2.1 \mathrm{~kJ} \mathrm{~mol}^{-1}$, and $\mathbf{1 c}=146.6$ $\pm 3.2 \mathrm{~kJ} \mathrm{~mol}^{-1}$. The uncertainties assigned are twice the overall standard deviations of the mean.

Enthalpies of F ormation. The enthalpies of formation of the three quinoxaline-1,4-dioxide derivatives were obtained from the corresponding standard enthal pies of formation in the crystalline state and from their enthalpies of sublimation. The final standard molar enthalpies of formation, in both crystalline and gaseous states, as well as the standard molar enthal pies of sublimation, at $\mathrm{T}=298 \mathrm{~K}$, for the compounds studied in this work are summarized in Table 4. The enthal pies of formation, in the gaseous state, are $149.4 \pm 4.5,-178.0 \pm 4.3$, and $249.2 \pm 6.6 \mathrm{~kJ} / \mathrm{mol}$ for $\mathbf{1 a}, \mathbf{1 b}$, and $\mathbf{1 c}$, respectively.<smiles>c1ccc2nccnc2c1</smiles>

3

Calculated Structures and Enthalpies of F ormation. Selected geometrical parameters of $\mathbf{3}$ and $\mathbf{2 a}$ obtained at the B3LYP/6-311+G(2d,2p) level of theory are compared with previous theoretical and experimental data in Table S4 (Supporting I nformation). 16,17 To allow a better comparison with previous works, we have considered the same atom labeling used in ref 16 and shown in Figure 1. Direct comparison with previous computed data at the B3LYP/6-31G(d) level of theory

(15) Burkinshaw, P. M.; Mortimer, C. T. J . Chem. Soc., Dalton Trans. 1984, 75-77.

(16) Matteo, A.; Valentin, M.; Giacometti, G.; Barone, V. Chem. Phys. Lett. 2001, 335, 427-434.

(17) Wozniak, K.; Krygowski, T. M.; Kariuki, B.; J ones, W. Acta Crystallogr. 1990, 46, 1946-1947.

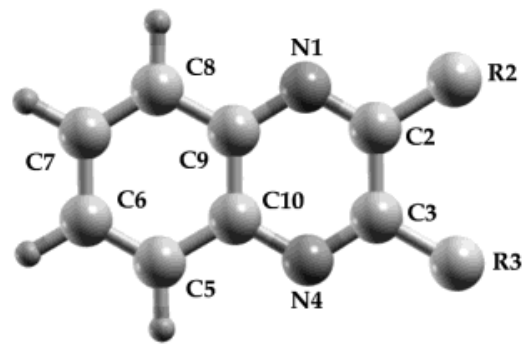

FIGURE 1. Atom labeling of derivatives of $\mathbf{3}$ and $\mathbf{2}$.

shows that the inclusion of diffuse functions and extra polarization functions does not significantly affect the geometry of either $\mathbf{3}$ or $\mathbf{2} \mathbf{a}$. However, it is noticed that the use of the $6-311+G(2 d, 2 p)$ basis set yields shorter bond lengths with a maximum deviation of $0.006 \AA$. The analysis of bond angles computed by these two different basis sets shows that differences are of about $\sim 0.2^{\circ}$ except in one case where a deviation of $0.8^{\circ}$ is found. Thus, we may conclude that the $6-31 \mathrm{G}(\mathrm{d})$ basis set is sufficient to describe the geometrical parameters of this class of compounds since differences are negligible when a larger basis is used. Comparison of calculated geometries and experimental crystallographic parameters shows an overall good agreement, but since solid and gasphase structures are compared, differences of up to 0.15 $\AA$ are found for $\mathrm{C}-\mathrm{H}$ bonds. The structural parameters of $\mathbf{3}$ and $\mathbf{2 a}$ are very similar, and the largest discrepancy is noticed for the $\mathrm{C} 2-\mathrm{C} 3$ bond. The elongation of this bond in $\mathbf{2 a}$ is due to the steric interaction of the methyl groups connected to adjacent carbon atoms.

Due to the larger size of the ethoxycarbonyl and benzyl substituents, the structure of the corresponding $\mathbf{2} \mathbf{b}$ and $\mathbf{2 c}$ derivatives is no longer planar and the deviation from planarity increases drastically with the size of the $R$ group. In the case of $\mathbf{2} \mathbf{b}$, the oxygen atoms are moved away from the quinoxaline plane by $30^{\circ}$. In the case of the benzyl substituent, $\mathbf{2 c}$, the presence of a $\mathrm{CH}_{2}$ group between the phenyl group and the quinoxal ine aromatic rings gives the chance for a larger tilt of the phenyl group. In the last case, the N4C3R 3 C and C2C3R 3 C dihedral angles are of 102 and $-78^{\circ}$, respectively. In this geometry, the phenyl ring is almost normal to the quinoxaline plane. Full geometric details are given in Supporting Information.

Different basis sets were used to estimate the enthal py of formation of $\mathbf{2 a}$ considering eq 1 .

$$
2 \mathrm{a}+2 \mathrm{CH}_{4} \rightarrow \mathbf{3}+2 \mathrm{CH}_{3} \mathrm{CH}_{3}
$$

The influence of the basis set chosen to describe the atomic density in the computed enthal py of formation is reported in Table 5. The results herewith reported show that the enthalpy of formation computed at the B $3 L Y P$ level of theory practically does not change with the size of the basis set considered. In fact, the addition of polarization and diffuse functions to the 6-31G(d) basis set produce changes in the calculated enthal py of formation of about $1 \mathrm{~kJ} / \mathrm{mol}$. Contrary to what was found in previous works for phenol derivatives ${ }^{18}$ and chloronitroanilines, ${ }^{19}$ the BP86 functional is shown to be poorer than

(18) Gomes, J . R. B.; Ribeiro da Silva, M. A. V. J . Phys. Chem. A. 2003, 107, 869-874. 
TABLE 5. Enthalpy of Formation of 2a Estimated from DFT Enthalpies $(T=298.15 \mathrm{~K}$ ) Calculated by Different Basis Sets and Different Reactions (Please See Text)a

\begin{tabular}{lccc}
\hline & $\begin{array}{c}\text { reaction } \\
\text { (eq 1) }\end{array}$ & $\begin{array}{c}\text { bond } \\
\text { dissociation } \\
\text { (eq 2) }\end{array}$ & $\begin{array}{c}\text { reaction } \\
\text { (eq 3) }\end{array}$ \\
\hline B3LYP/6-31G(d) & 165.4 & 157.2 & 182.3 \\
B3LYP/6-31+G(d,p) & 165.3 & & \\
B3LYP/6-311+G(2d,2p)// & 167.5 & & \\
B3LYP/6-31G(d) & 166.5 & 176.9 & 180.4 \\
B3LYP/6-311+G(2d,2p) & 161.9 & & \\
BP86/6-31+G(d,p) & 16.9 & \\
a Values are given in kJ /mol. & & \\
\hline
\end{tabular}

the B $3 L$ YP approach in the present calculations. The value in closer agreement with experiment was calculated from a combined approach that used the B3LYP/ 6-31G(d) level to compute vibrational frequencies and the B3L YP/6-311+G(2d,2p) level to obtain the total energy after optimization with this larger basis set. In the present work, the combined approach is labeled B3LYP/ $6-311+G(2 d, 2 p) / / B 3 L Y P / 6-31 G(d)$. At this level of theory, the enthalpy of formation of $\mathbf{2 a}$ is $167.5 \mathrm{~kJ} / \mathrm{mol}$.

For all the basis sets considered and when used together with the B $3 \mathrm{~L}$ Y P exchange-correlation functional or even with the BP86 functional, the calculated enthalpies of formation are al ways lower than the experimental value reported for $\mathbf{2 a}, 172.9 \pm 3.0 \mathrm{~kJ} / \mathrm{mol}^{11} \mathrm{H}$ owever, if we analyze what happens when a new reaction is used, there are significant changes in the computed values. The enthalpies of formation calculated from the use of two new reaction schemes, bond dissociation (eq 2) and a different isodesmic reaction (eq 3), are also compiled in Table 5. F rom the bond dissociation reaction (eq 2 ), the computed enthalpy of formation is rather decreased if the $6-31 G(d)$ basis set is used. However, if a $6-311+G(2 d$,$2 p)$ basis set is used, the calculated enthalpy of formation is now very close to the available experimental result. This estimation is based on the experimental enthalpies of formation of all compounds in eq 2. The only exception was the enthalpy of formation of methylenimine, $\mathrm{CH}_{2}$ $\mathrm{NH}$. In a recent computational study, De Oliveira et al. ${ }^{20}$ used the accurate W2 (Weizmann-2) thermochemical approach to calculate the enthalpy of formation of methylenimine. These authors claim that their value, 88.3 $\pm 2.1 \mathrm{~kJ} / \mathrm{mol}$, carries a much smaller uncertainty than any available experimental results, which lie in the range $86.2-110.5 \mathrm{~kJ} / \mathrm{mol} .{ }^{20}$ The $\mathrm{W} 2$ value is in agreement with the most recent experimental results, $87.9 \pm 16.7 \mathrm{~kJ} /$ mol. ${ }^{21,22}$ In the present work, the enthalpy of formation of $\mathrm{CH}_{2} \mathrm{NH}$ was recalculated by using the Gaussian-3 approach and the reaction of atomization. The computed number is $87.4 \mathrm{~kJ} / \mathrm{mol}$, in excellent agreement with the recent and accurate $\mathbf{W} 2$ calculations. ${ }^{20}$ The enthal py of formation of $\mathbf{2 a}$ was also computed by using a third

(19) Ribeiro da Silva, M. A. V.; Lima, L. M. S. S.; Amaral, L. M. P F.; Ferreira, A. I. M. C. L.; Gomes, J . R. B. J . Chem. Thermodyn. 2003, 35, 1343-1359.

(20) De Oliveira, G.; Martin, J . M. L.; Silwal, I. K. C.; Liebman, J . F. J. Comput. Chem. 2001, 22, 1297-1305.

(21) Tarasenko, N. A.; Tishenkov, A. A.; Zaikin, V. G.; Volkova, V. V.;Gusel'nikov, L. E. IzvestiaAkademia NaukSSSR, Seriya Khimicheskaya 1986, 2397.

(22) Holme, J . L.; Lossing, F. P.; Mayer, P. M. Chem. Phys. Lett. 1992, 198, 211-213. reaction (eq 3) and the B3LYP/6-31G(d) or the B3LYP/ $6311+\mathrm{G}(2 \mathrm{~d}, 2 \mathrm{p})$ approaches. Again, due to the large uncertainty associated with the experimental enthalpy of formation of the $\mathrm{CH}_{2} \mathrm{NCH}_{3}$ species, $44 \pm 8 \mathrm{~kJ} / \mathrm{mol}$, ${ }^{23}$ this value was estimated from Gaussian-3 calculations. The G3-computed enthalpy of formation for this species is $78.6 \mathrm{~kJ} / \mathrm{mol}$. This number differs significantly from the available experimental result, ${ }^{23}$ and thus the enthal pies of formation of $\mathbf{2 a}$ estimated by employing reaction 3 must be analyzed with caution. However, since the G3 approach yields an enthalpy of formation for methylenimine that is in excel lent agreement with the most recent experimental ${ }^{21,22}$ and theoretical results ${ }^{20}$ for $\mathrm{CH}_{2} \mathrm{NH}$, we believe that the computed value for the $\mathrm{CH}_{2} \mathrm{NCH}_{3}$ species presents also a small uncertainty. Thus, it is expected that this approach would permit the estimation of the enthalpy of formation of the similar $\mathrm{CH}_{2} \mathrm{NCH}_{3}$ species. The enthalpies of formation estimated by employing reaction 3 are in fair agreement with the experimental number but somewhat larger than $172.9 \mathrm{~kJ} / \mathrm{mol}$.

$$
\begin{aligned}
& \mathbf{2 a}+2 \mathrm{CH}_{4}+2 \mathrm{NH}_{3} \rightarrow \\
& 6 \mathrm{CH}_{3} \mathrm{CH}_{3}+3 \mathrm{CH}_{2} \mathrm{CH}_{2}+2 \mathrm{CH}_{3} \mathrm{NH}_{2}+2 \mathrm{CH}_{2} \mathrm{NH} \\
& \mathbf{2 a}+2 \mathrm{CH}_{4}+2 \mathrm{CH}_{2} \mathrm{CHCH}_{3} \rightarrow \\
& \text { naphthalene }+2 \mathrm{CH}_{3} \mathrm{CH}_{3}+2 \mathrm{CH}_{2} \mathrm{NCH}_{3}
\end{aligned}
$$

From what is shown in Table 5, it may be concluded that the use of the B3LYP approach to estimate the enthalpy of formation of the $\mathbf{2 a}$ compound gives a maximum uncertainty of $10 \mathrm{~kJ} / \mathrm{mol}$, which is lowered to 3-6 kJ /mol if the 6-311+G $(2 \mathrm{~d}, 2 \mathrm{p})$ basis set is employed.

The enthal pies of formation of the other two 2-methyl3-(R)-quinoxaline derivatives, $\mathbf{2} \mathbf{b}$ and $\mathbf{2 c}$, were estimated from the following isodesmic reaction.

$$
2+2 \mathrm{CH}_{3} \mathrm{CH}_{3} \rightarrow 3+\mathrm{CH}_{3} \mathrm{R}
$$

The standard enthalpy of formation of $\mathbf{2 b}$ is -159.2 $\mathrm{kJ} / \mathrm{mol}$ at the B3LYP/6-311+G(2d,2p) level of theory or $-159.8 \mathrm{~kJ} / \mathrm{mol}$ at the B $3 \mathrm{~L} Y \mathrm{P} / 6-311+\mathrm{G}(2 \mathrm{~d}, 2 \mathrm{p}) / / \mathrm{B} 3 \mathrm{~L} Y \mathrm{P} / 6-$ $31 \mathrm{G}$ (d) level, respectively. Again, in agreement with the results reported in Table 5, negligible differences are found between the B3LYP/6-311+G(2d,2p) and B3LYP/ $6-311+G(2 d, 2 p) / / B 3 L Y P / 6-31 G(d)$ calculated enthal pies of formation. Thus, to save some computer time, the enthalpy of formation of the benzyl derivative was estimated only from the enthalpies computed by the combined approach. Using the latter approach afforded an estimated value for $\mathbf{2 c}$ of $289.4 \mathrm{~kJ} / \mathrm{mol}$, not far from the B3LYP/6-31G(d) result, which is $286.1 \mathrm{~kJ} / \mathrm{mol}$.

The enthalpy of formation of $\mathbf{l a}$ was calculated at the $B 3 L Y P / 6-311+G(2 d, 2 p)$ level using reaction 5 and the experimental enthalpy of formation of $\mathbf{2 a}, 172.9 \pm 3.0$ $\mathrm{kJ} / \mathrm{mol},{ }^{11}$ and al so $\Delta_{\mathrm{f}} \mathrm{H}_{\mathrm{m}}^{\mathrm{O}}(\mathrm{O}, \mathrm{g})=249.18 \pm 0.10 \mathrm{~kJ} / \mathrm{mol}^{14}$ The computed value is $149.6 \mathrm{~kJ} / \mathrm{mol}$, in excellent agreement with the experimental value, $149.4 \pm 4.5 \mathrm{~kJ} / \mathrm{mol}$. However, the gas-phase enthal pies of formation of $\mathbf{1 b}$ and 1c were not calculated due to the absence of experimental enthalpies of formation for $\mathbf{2} \mathbf{b}$ and $\mathbf{2 c}$.

(23) Peerboom, R. A. L.; Ingemann, S.; Nibbering, N. M. M. Liebman, J . F. J . Chem. Soc., Perkin Trans. 1990, 2, 1825-1828.

2788 J. Org. Chem., Vol. 69, No. 8, 2004 
TABLE 6. Gas-Phase Enthalpies of Formation and Derived Mean $(\mathbf{N}-\mathbf{O})$ Bond Molar Dissociation Enthalpies for $\mathrm{la}-\mathrm{C}$, at $\mathrm{T}=298.15 \mathrm{~K}$, and Gas-Phase Enthalpies of Formation for $2 a-c$

\begin{tabular}{|c|c|c|c|}
\hline \multirow[b]{2}{*}{$\mathrm{R}$} & \multicolumn{2}{|c|}{$\Delta_{\mathrm{f}} \mathrm{H}_{\mathrm{m}}^{\mathrm{O}}(\mathrm{g})$} & \multirow[b]{2}{*}{$\left\langle\mathrm{DH}_{\mathrm{m}}^{\mathrm{O}}(\mathrm{N}-\mathrm{O})\right\rangle$} \\
\hline & 1 & 2 & \\
\hline $\begin{array}{l}\mathbf{a} \\
\mathbf{b} \\
\mathbf{c}\end{array}$ & $\begin{array}{r}149.4 \pm 4.5 \\
-178.0 \pm 4.3 \\
249.2 \pm 6.6\end{array}$ & $\begin{array}{r}172.9 \pm 3.0^{b} \\
-159.2 \pm 5.0^{c} \\
289.4 \pm 5.0^{c}\end{array}$ & $\begin{array}{l}260.9 \pm 2.7 \\
258.6 \pm 3.3 \\
269.3 \pm 4.1\end{array}$ \\
\hline
\end{tabular}

a Values are given in $\mathrm{kJ} / \mathrm{mol} .{ }^{\mathrm{b}}$ Experimental value taken from ref $11 .{ }^{\mathrm{C}}$ B $3 L Y P$ value, this work; deviation was estimated.

$\mathbf{N}-\mathbf{O}$ Bond Dissociation Enthalpies. The standard enthalpy of formation in the gaseous state of these quinoxaline 1,4-dioxide derivatives gives the basis for the knowledge of their thermodynamic behavior and also of the energetics of their mean $(\mathrm{N}-\mathrm{O})$ bonds. The mean $(\mathrm{N}-\mathrm{O})$ bond dissociation enthalpy, $\left\langle\mathrm{DH}_{\mathrm{m}}^{\mathrm{O}}(\mathrm{N}-\mathrm{O})\right\rangle$, for $\mathbf{1}$, corresponds to one-half of the enthalpy of the gaseous reaction 5, requiring the enthalpy of formation of $\mathbf{2}$ and also of atomic oxygen. ${ }^{11,14}$

$$
\mathbf{1}(\mathrm{g})=\mathbf{2}(\mathrm{g})+20(\mathrm{~g})
$$

The derived values for $\left\langle\mathrm{DH}_{\mathrm{m}}^{\mathrm{O}}(\mathrm{N}-\mathrm{O})\right\rangle$ are listed in Table 6, together with the experimental values for the gas-phase enthalpies of formation for $\mathbf{1 a}-\mathbf{c}$ and the literature value for the gaseous enthal py of formation for 2a. The computationally derived enthalpies of formation for $\mathbf{2 b}$ and $\mathbf{2 c}$ are also reported in Table 6 . The $\left\langle\mathrm{DH}_{\mathrm{m}}^{\mathrm{O}}(\mathrm{N}-\mathrm{O})\right\rangle$ results obtained are included in the range defined by the experimental $\left\langle\mathrm{DH}_{\mathrm{m}}^{\mathrm{O}}(\mathrm{N}-\mathrm{O})\right\rangle$ previously obtained $^{1 \mathrm{~b}}$ for two other quinoxaline di-N-oxide derivatives, namely, $\mathbf{l d}\left(\left\langle\mathrm{DH} \mathrm{m}_{\mathrm{m}}^{\mathrm{O}}(\mathrm{N}-\mathrm{O})\right\rangle=268.3 \pm 4.9 \mathrm{~kJ} / \mathrm{mol}\right)$ and $\mathbf{l e}\left(\left\langle\mathrm{DH} \mathrm{m}_{\mathrm{m}}^{\mathrm{O}}(\mathrm{N}-\mathrm{O})\right\rangle=242.3 \pm 3.9 \mathrm{~kJ} / \mathrm{mol}\right)$.

The $(\mathrm{N}-\mathrm{O})$ bond dissociation enthal pies (BDE) have been calculated considering the computed enthal pies at the B3LYP level of theory for $\mathbf{1 a}-\mathbf{c}$ and their products obtained from removal of one oxygen or two oxygen atoms. The calculated ( $\mathrm{N}-\mathrm{O})$ BDEs are reported in Figures 2-4. For $\mathbf{1 a}$, the first, second, and mean $(\mathrm{N}-\mathrm{O})$ BDE $s$ at the B3LYP/6-31G(d) level are 255.6, 274.5, and $265.0 \mathrm{~kJ} / \mathrm{mol}$, respectively, cf. Figure 2. At the B3LYP/ $6-311+G(2 d, 2 p)$ level of theory, these values are 252.4, 269.2, and $260.8 \mathrm{~kJ} / \mathrm{mol}$, for the first, second and mean $(\mathrm{N}-\mathrm{O}) \mathrm{BDEs}$, respectively. The mean $(\mathrm{N}-\mathrm{O}) \mathrm{BDE}$ is identical to the experimental determined value, $260.9 \pm$ $2.7 \mathrm{~kJ} / \mathrm{mol}$, and also to the computed value obtained by the combined B3LYP/6-311+G(2d,2p)//B3LYP/6-31G(d) approach, $260.6 \mathrm{~kJ} / \mathrm{mol}$. The combined B3LYP/6-311+G(2d,2p)//B3LYP/6-31G(d) approach yiel ds N-O BDEs that are in close agreement with those computed by the B3LYP/6-311+G(2d,2p) approach, which demands much greater computing resources. Thus, to save computing time, the combined approach was used for the other two dioxide derivatives. The computed $\left\langle\mathrm{DH}_{\mathrm{m}}^{\mathrm{O}}(\mathrm{N}-\mathrm{O})\right\rangle$ value for the ethoxycarbonyl derivative, $\mathbf{1 b}$, is $255.0 \mathrm{~kJ} / \mathrm{mol}$, Figure 3, while for the benzyl derivative, 1c, this value is $260.1 \mathrm{~kJ} / \mathrm{mol}$, Figure 4. These numbers are also in rather good agreement with the experimental values reported in Table 6 . Analysis of the energy required to remove only one oxygen atom shows that the oxygen atom closest to the bulkiest ligand is much more easily removed, i.e., the $\mathrm{N}-\mathrm{O}$ bond dissociation energy is lower. In the case of $\mathbf{1 b}$, the energy required to remove the ethoxycarbonyl neighboring oxygen atom is $242.9 \mathrm{~kJ} / \mathrm{mol}$, almost $10 \mathrm{~kJ} / \mathrm{mol}$ less than that required to remove the oxygen atom adjacent to the methyl group. I dentically, for $\mathbf{1 c}$ the energy required to remove the oxygen atom closest to the benzyl group is lower than that required to remove the $\mathrm{CH}_{3}$ neighboring oxygen atom. However, in the latter case, the energetic difference is only $\sim 3 \mathrm{~kJ} /$ $\mathrm{mol}$. The larger energetic difference found for $\mathbf{1 b}$ is in agreement with previous experimental information. ${ }^{24}$ Dirlam and McFarland ${ }^{24}$ found that it is possible to selectively remove the oxygen atom closest to the $\mathrm{C}(\mathrm{O})$ $\mathrm{OCH}_{3}$ group in le. They observed that the reaction yield is larger than $95 \%$ after reaction with excess trimethyl phosphite in refluxing 1-propanol. ${ }^{24}$

\section{Conclusions}

In the present work, both experimental and computational techniques were used to obtain the enthal pies of formation and $\mathrm{N}-\mathrm{O}$ bond dissociation enthal pies, in the gas-phase, for $\mathbf{1 a}-\mathbf{c}$. The final experimental results are reported in Table 6 . The $\mathrm{N}-\mathrm{O}$ BDEs calculated at the DFT-based B3LYP level of theory are in rather good agreement with these experimental values. The results obtained show that the first $\mathrm{N}-\mathrm{O}$ bond dissociation enthalpy increases in the order ethoxycarbonyl < benzyl $<$ methyl. The second $\mathrm{N}-\mathrm{O}$ bond dissociation enthal pies are almost the same for the three compounds studied due to similar neighboring, i.e., a methyl group in an adjacent position. The second $\mathrm{N}-\mathrm{O}$ bond dissociation enthalpies, corresponding to the oxygen atom nearest to the $\mathrm{CH}_{3}$ group, are of about $267-269 \mathrm{~kJ} / \mathrm{mol}$. These results show that the oxidizing power of $\mathbf{1}$ derivatives is highly increased if bulky ligands appear in positions near the $\mathrm{N}-\mathrm{O}$ moiety, especially if they have atoms with lone pairs. However, the presence of nearby bulky substituents is not the full answer to the synthesis of new highly oxidizing agents. A dramatic increase of the size of the ligand disables the synthesis of 1-4-dioxides due to enormous destabilization of these molecules.

\section{Experimental Section}

Materials. la was prepared by reacting benzofuroxan with 2-butanone as described by Heyns et al. ${ }^{25}$ The compound was further purified by three crystallizations from anhydrous methanol. 1b was synthesized as previously published in the literature. ${ }^{26}$ The procedure involved the addition of ethylacetoacetate to an ice-cooled methanol ic solution of benzofuroxan. Morpholine was added dropwise with stirring, and the resulting mixture was stirred overnight. The crude product that was collected by filtration was further purified by three crystallizations from absolute ethanol. 1c was prepared in similar fashion from benzylacetone and benzofuroxan, using butylamine as the base. ${ }^{27} \mathrm{~A}$ purified sample of $\mathbf{1 c}$ was obtained by three crystallizations from ethanol.

Experimental melting point temperatures of $\mathbf{l a}-\mathbf{c}$, along with published literature values, are given in Supporting Information. 1364.

(24) Dirlam, J . P.; McFarland, J . W. J . Org. Chem. 1977, 42, 1360245.

(26) Monge-Vega, A.; Gil, M. J .; Fernandez-Alvarez, E.J . Heterocycl. Chem. 1984, 21, 1271-1275.

(27) J arrar, A. A.; Fataftah, Z. A. Tetrahedron 1977, 33, 2127-2129. 


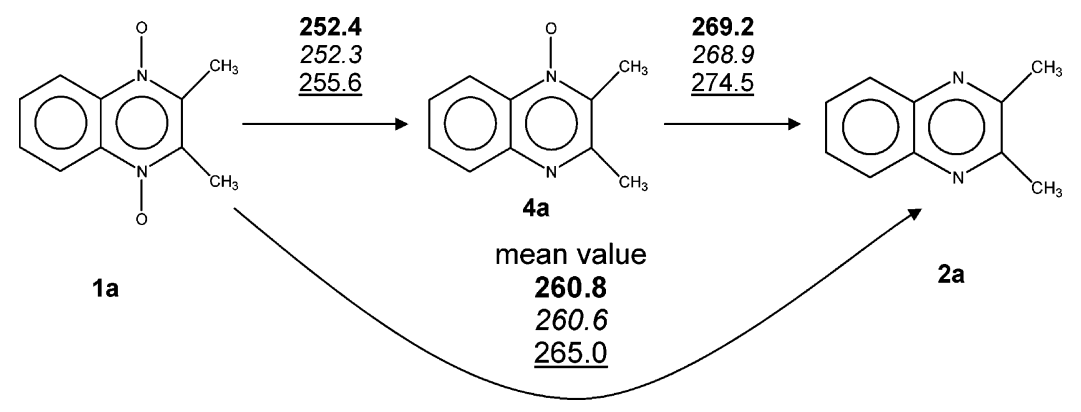

FIGURE 2. Computed first, second, and mean $(\mathrm{N}-\mathrm{O})$ BDEs for $\mathbf{l a}$. Values are given in $\mathrm{kJ} / \mathrm{mol}$. Results computed at the B3LYP/ $6-311+G(2 d, 2 p)$ level of theory are shown in bold. Results obtained by the combined B 3LYP/6-311+G(2d,2p)//B3LYP/6-31G(d) approach are shown in italics. Finally, underlined text shows the results computed at the B3LYP/6-31G(d) level of theory.

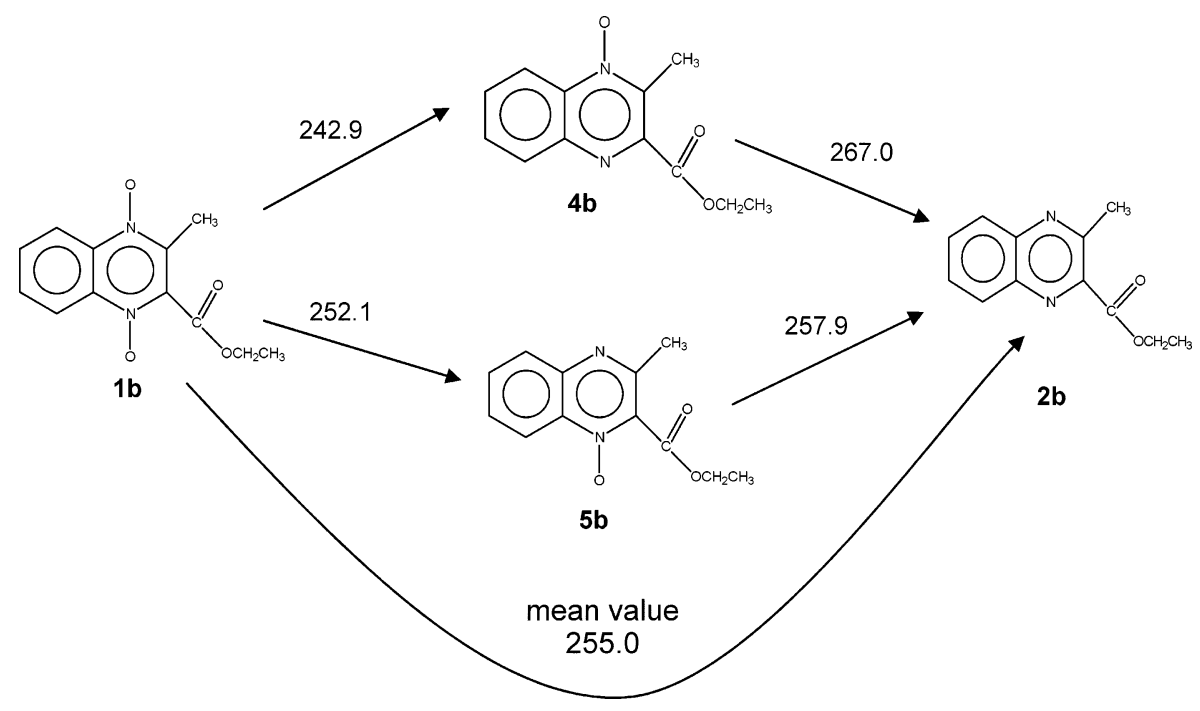

FIGURE 3. First, second, and mean $(\mathrm{N}-\mathrm{O}) \mathrm{BDE}$ for $\mathbf{1 b}$. Values are given in $\mathrm{kJ} / \mathrm{mol}$ and were computed at the B $3 L \mathrm{YP} / 6-311+\mathrm{G}-$ $(2 \mathrm{~d}, 2 \mathrm{p}) / / \mathrm{B} 3 \mathrm{~L} Y \mathrm{P} / 6-31 \mathrm{G}(\mathrm{d})$ level of theory.

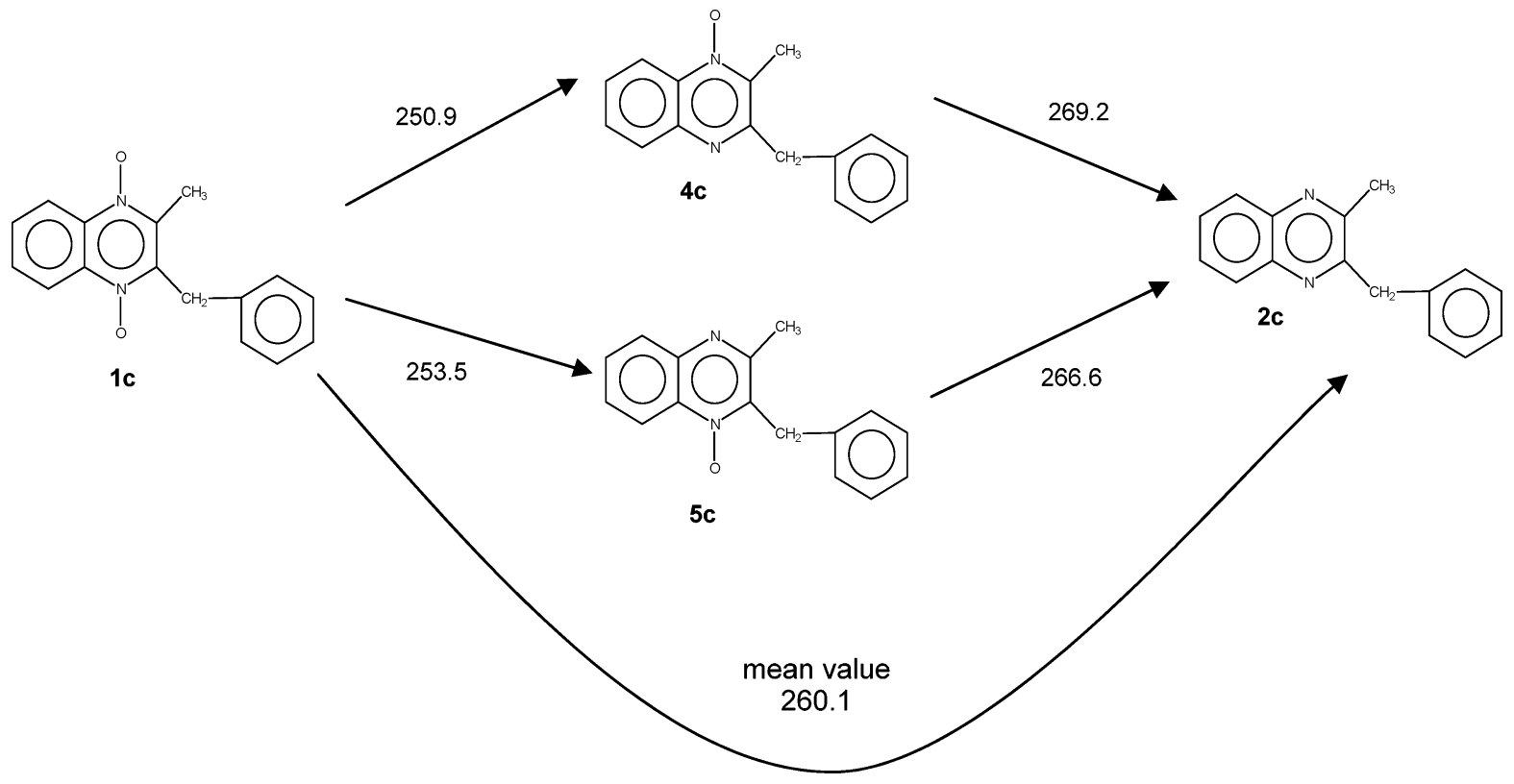

FIGURE 4. First, second, and mean $(\mathrm{N}-\mathrm{O}) \mathrm{BDEs}$ for $\mathbf{1 c}$. Values are given in $\mathrm{kJ} / \mathrm{mol}$ and were computed at the B3L YP/6-311+G$(2 d, 2 p) / / B 3 L Y P / 6-31 G(d)$ level of theory.

Elemental analyses were in agreement with calculated values. Mass fractions for $\mathrm{C}_{10} \mathrm{H}_{10} \mathrm{~N}_{2} \mathrm{O}_{2}$ : found $\mathrm{C}, 0.6311 ; \mathrm{H}$, 0.0542; N, 0.1480; calcd C, 0.6315; H, 0.0530; N, 0.1473. For
$\mathrm{C}_{12} \mathrm{H}_{12} \mathrm{~N}_{2} \mathrm{O}_{4}$ : found $\mathrm{C}, 0.5815 ; \mathrm{H}, 0.0472 ; \mathrm{N}, 0.1135$; calcd: $\mathrm{C}$, 0.5806; $\mathrm{H}, 0.0487 ; \mathrm{N}, 0.1128$. For $\mathrm{C}_{16} \mathrm{H}_{14} \mathrm{~N}_{2} \mathrm{O}_{2}$ : found C, 0.7231; H, 0.0538; N, 0.1060; calcd C, 0.7216; H, 0.0530; N, 0.1052 .

2790 J. Org. Chem., Vol. 69, No. 8, 2004 
Thermochemical Measurements. The energies of combustion of the three compounds were determined with an isoperibol static bomb calorimeter, with a twin-valve bomb with an internal volume of $0.290 \mathrm{dm}^{3}$, which has been transferred from Manchester to Porto. The apparatus was used mainly as previously described, ${ }^{28,29}$ but with a few changes in technique because of different auxiliary equipment used, as it is described in ref $1 f$.

The energy of reaction was always referred to as the initial temperature of $298.15 \mathrm{~K}$. The cal orimetric system was calibrated using benzoic acid (BDH Thermochemical Standard, batch 693976/01) having a massic energy of combustion under standard bomb conditions of $-26435.1 \pm 3.5 \mathrm{~J} / \mathrm{g}$. The calibration results were corrected to give the energy equival ent e(cal) corresponding to an average mass of water added to the cal orimeter of $2900.0 \mathrm{~g}$. One set of seven calibration experiments was made in oxygen at $p=3.04 \mathrm{MPa}$, with $1.00 \mathrm{~cm}^{3}$ of water added to the bomb, leading to an energy equivalent of the calorimeter e(calor) $=15551.6 \pm 2.6 \mathrm{~J} / \mathrm{K}$, where the uncertainty quoted is the standard deviation of the mean. To check the accuracy of the apparatus, a series of six experiments was also performed by burning urea (NBS, Standard Reference Material 2152, having a massic energy of combustion under standard bomb conditions of $-10536 \pm 3 \mathrm{~J} / \mathrm{g}$ ) in the presence of an auxiliary material of combustion (benzoic acid, BCS-CRM 190-r, having a massic energy of combustion under standard bomb conditions of $-26432.3 \pm 3.8 \mathrm{~J} / \mathrm{g}$ ). The result obtained, $-10534.7 \pm 4.0 \mathrm{~J} / \mathrm{g}$, agrees with the certified one.

Samples of compounds in pellet form were ignited at $\mathrm{T}=$ $298.150 \pm 0.001 \mathrm{~K}$ in oxygen at a pressure $\mathrm{p}=3.04 \mathrm{MPa}$ with a volume of $1.00 \mathrm{~cm}^{3}$ of water added to the bomb. The electrical energy for ignition was determined from the change in potential difference across a capacitor when discharged through the platinum ignition wire. $n-H$ exadecane, $\Delta_{c} \mathrm{u}^{\mathrm{O}}=-47164.3$ $\pm 3.6 \mathrm{~J} / \mathrm{g}$, was used as an auxiliary in the combustion experiments for 1c. The corrections for the cotton thread fuse, carbon formation, and nitric acid formation were made as previously described. ${ }^{30}$ At $T=298.15 \mathrm{~K}$, ( $\left.\partial \mathrm{u} / \partial \mathrm{p}\right)_{\mathrm{T}}$ for this solid was assumed to be $-0.2 \mathrm{~J} \mathrm{~g}^{-1} \mathrm{MPa}^{-1}$, a typical value for organic solids.

For all the compounds, the values of $-\Delta_{c} u^{0}$ were calculated by the procedure given by Hubbard et al. ${ }^{12}$ The relative atomic masses used throughout this paper were those recommended by the IUPAC Commission in 1999.11 The amount of substance used in each experiment was determined from the total mass of carbon dioxide produced after allowance for that formed from the cotton thread fuse, n-hexadecane, and that lost due to carbon formation. Assuming $\rho=1.00$, the average ratios, $\langle r\rangle$, of the mass of carbon dioxide produced by the samples during the energy of combustion measurement to that calculated from its mass with uncertainties of twice the standard deviation of the mean were as follows: for $\mathbf{1 a},\langle r\rangle=1.0000 \pm$ 0.0005 ; for $\mathbf{1 b},\langle r\rangle=0.9998 \pm 0.0004$; and for $\mathbf{1 c},\langle\mathbf{r}\rangle=0.9666$ \pm 0.0006 .

The enthal pies of sublimation of the three compounds were measured by the "vacuum sublimation" drop microcalorimetric method ${ }^{32}$ in a Calvet High-Temperature Microcalorimeter (SETARAM HT 1000), held at the temperature T = $419 \mathrm{~K}$ for $\mathbf{1 a}, \mathrm{T}=412 \mathrm{~K}$ for $\mathbf{1 b}$, and $\mathrm{T}=435 \mathrm{~K}$ for $\mathbf{1 c}$. The standard molar enthalpies of sublimation $\left\{\mathrm{H}_{\mathrm{m}}^{\mathrm{O}}(\mathrm{g}, \mathrm{T})-\mathrm{H}_{\mathrm{m}}^{\mathrm{O}}(\mathrm{cr}\right.$, $298.15 \mathrm{~K})\}$ were corrected to $\mathrm{T}=298.15 \mathrm{~K}$ using a value of

(28) Gundry, H. A.; Harrop, D.; Head, A. J .; Lewis, G. B. J . Chem. Thermodyn. 1969, 1, 321-332.

(29) Bickerton, J .; Pilcher, G.; Al-Takhin, G. J . Chem. Thermodyn. 1984, 16, 373-378.

(30) Coops, J .; J essup, R. S.; Van Nes, K. In Experimental Thermochemistry; Rossini, F. D., Ed.; Interscience: New York, 1956; Vol. 1, Chapter 3.

(31) Coplen, T. B. J . Phys. Chem. Ref. Data 2001, 30, 701-712.

(32) Adedeji, F. A.; Brown, D. L. S.; Connor, J . A.; Leung, M.; Paz Andrade, M. I.; Skinner, H. A. J . Organomet. Chem. 1975, 97, 221228.
$\Delta_{298.15 K^{\top}} H_{m}^{O}(g)$ estimated by a group method based on the values of Stull et al. ${ }^{33}$ The microcal orimeter was calibrated in situ for these measurements by making use of the reported molar enthal py of sublimation, at $\mathrm{T}=298.15 \mathrm{~K}$, of naphthalene, $\mathrm{C}_{10} \mathrm{H}_{8}: 72.51 \pm 0.01 \mathrm{~kJ} / \mathrm{mol}^{34}$

Some problems occurred during the microcalorimetric measurements, particularly for $\mathbf{1 c}$, related to the low vapor pressure of the compounds and incomplete sublimation of the samples in some of the runs. The enthalpies of sublimation were then deduced from the temperature dependence of the vapor pressures. The standard molar enthal pies of sublimation of the three compounds were measured by the Knudsen effusion method using the apparatus as described by Burkinshaw, ${ }^{15}$ with the detailed modifications previously reported..$^{35}$ The equipment was tested with several compounds of known standard molar enthalpies of sublimation (benzanthrone, squaric acid, and 4-hydroxy-2-methylquinoline), and good agreement with the literature values was obtained. The vapor effusing from the Knudsen cell was allowed to condense on a quartz crystal positioned above the effusion hole; changes in the frequency $\Delta f$ of oscillation of the quartz crystal were proportional to the mass condensed on its surface, ${ }^{36} \Delta f=C_{f} \Delta m$, where $\mathrm{C}_{\mathrm{f}}$ is a proportionality constant.

From the Knudsen equation,

$$
\mathrm{p}=(\Delta \mathrm{m} / \Delta \mathrm{t}) \cdot \mathrm{a}^{-1} \cdot(2 \pi \mathrm{RT} / \mathrm{M})^{1 / 2}
$$

where $(\Delta \mathrm{m} / \Delta \mathrm{t})$ is the rate of mass loss, a is the effective area of the effusion hole, and $M$ is the molar mass of the effusing vapor. As the measured rate of change of frequency of oscillation with time, $v=\Delta \mathrm{f} / \Delta \mathrm{t}$, is directly proportional to the rate of sublimed mass ${ }^{36}$ of the crystalline sample, $v=\mathrm{C}_{f} \Delta \mathrm{m} /$ $\Delta \mathrm{t}$,

$$
\mathrm{p}=v \cdot \mathrm{T}^{1 / 2} \cdot(2 \pi \mathrm{R} / \mathrm{M})^{1 / 2} /\left(\mathrm{a} \cdot \mathrm{C}_{\mathrm{f}}\right)
$$

By applying the integrated form of the Clausius-Clapeyron equation, the enthalpy of sublimation, $\Delta_{c r} 9 H_{m}^{O}$, may be de rived from the slope of $\ln \left(v \top^{1 / 2}\right)$ against $\mathrm{T}^{-1}$. From five independent sets of experimental measurements of the fre quency of the quartz oscillator for each compound, at conve nient temperature intervals, it was possible to obtain five independent results for the enthalpy of sublimation of each compound, referred to as the mean temperature of the experimental range.

Computational Details. Density functional theory, DFT, calculations were carried out considering the B3LYP three parameter hybrid method proposed by Becke. ${ }^{37}$ The B3LYP method comprises an exchange-correlation functional that mixes the nonlocal Fock exchange with the gradient-corrected form of Becke $\mathrm{e}^{38}$ and adds the correlation functional proposed by Lee et al.39

The use of the B3LYP method with a relatively large basis set is known to be an excellent computational choice.18,40-44 This approach was found to provide very good molecular

(33) Stull, D. R.; Westrum, E. F.; Sinke, G. C. The Chemical Thermodynamics of Organic Compounds; Wiley: New York, 1969.

(34) De Kruif, C. G.; Kuipers, T.; Van Mittenburg, J . C.; Schaake, R. C. F.; Stevens, G. J. Chem. Thermodyn. 1981, 13, 1081-1086.

(35) Ribeiro da Silva, M. A. V.; Gonçalves, J . M. J . Chem. Thermodyn. 1998, 30, 1465-1481.

(36) Sauerbrey, G. Z. Phys. 1959, 155, 206-222

(37) Becke, A. D. J . Chem. Phys. 1993, 98, 5648-5652.

(38) Becke, A. D. Phys. Rev. A 1988, 38, 3098-3100.

(39) Lee, C.: Yang, W.: Parr, R. G. Phys. Rev. B 1988, 37, 785-789.

(40) Wright, J . S.; Carpenter, D. J .; McKay, D. J .; Ingold, K. U. J . Am. Chem. Soc. 1997, 119, 4245-4252.

(41) Gomes, J. R. B.; Illas, F. Catal. Lett. 2001, 71, 31-35.

(42) Gomes, J . R. B.; Illas, F. Int. J . Mol. Sci. 2001, 2, 211-220.

(43) Gomes, J. R. B.; Ribeiro da Silva, M. A. V. Inorg. Chem. Commun. 2003, 6, 149-153.

(44) Olleta, A. C.; Lane, S. I. Phys. Chem. Chem. Phys. 2001, 3, $811-$ 818 
geometries comparable to those obtained using more accurate and CCSD $(\mathrm{T})$ or QCISD methods, which demand much greater computer resources, together with a medium-sized basis set. ${ }^{41,42}$ Ther efore, use of an extended basis set is needed; unfortunately, this makes infeasible the application of these accurate methods to the majority of chemical compounds in which the chemists are interested, i.e., large-sized molecules and compounds containing heavy atoms. The success of the hybrid approach is also confirmed by the good agreement observed for phenoxyl radical's vibrational frequencies and spin densities computed at the DFT/6-31G(d) level of theory and those obtained experimentally or calculated using the more expensive CASSCF/6-311G(2d,p) approach. ${ }^{45}$

In this work, total energies for all the species were computed at the B3LYP level of theory but using different basis sets, all derived from the standard 6-31G(d) by augmentation with diffuse and polarization functions. These energies were corrected by including the zero-point energies, ZPE, as well as translational, rotational and vibrational contributions to the enthalpy at $T=298.15 \mathrm{~K}$, obtained by a calculation of vibrational frequencies at the samelevel of theory except when specified. All computations were performed by means of the GAMESS-US suite of programs ${ }^{46}$ except $\mathrm{G} 3$ calculations, which were performed with the Gaussian98 package. ${ }^{47}$

These enthalpies at $\mathrm{T}=298.15 \mathrm{~K}$ were then used to estimate the enthalpies of formation of the substituted quinoxalines considered in the present work and also to calculate the first and second $(\mathrm{N}-\mathrm{O})$ bond dissociation enthal pies of the corresponding quinoxalines-1,4-dioxides. The enthal py of formation of $\mathbf{2 a}-\mathbf{c}$ were estimated by combining the enthalpy of the isodesmic reactions 1 or 4 , cal culated from the previously computed thermally corrected energies of each species and the experimental enthal pies of formation for methane, $-74.85 \pm$ $0.31 \mathrm{~kJ} / \mathrm{mol},{ }^{48}$ quinoxaline, $240.3 \pm 3.3 \mathrm{~kJ} / \mathrm{mol},{ }^{49}$ ethane, -83.8 $\pm 0.3 \mathrm{~kJ} / \mathrm{mol}, 50$ ethyl acetate, $-444.8 \pm 0.4 \mathrm{~kJ} / \mathrm{mol},{ }^{51}$ and ethyl benzene, $29.8 \pm 0.84 \mathrm{~kJ} / \mathrm{mol} .{ }^{52}$ The $(\mathrm{N}-\mathrm{O})$ bond dissocia-

(45) Qin, Y.; Wheeler, R. A. J . Chem. Phys. 1994, 102, 1689-1698.

(46) GAMESS-US, version 14/01/2003: Schmidt, M. W.; Baldridge, K. K.; Boatz, J . A.; Elbert, S. T.; Gordon, M. S.; J ensen, J . H.; Koseki, S.; Matsunaga, N.; Nguyen, K. A.; Su, S. J .; Windus, T. L. Dupuis, M.; Montgomery, J. A. J . Comput. Chem. 1993, 14, 1347-1363. tion enthalpies have been calculated directly from previously computed thermally corrected energies of the several quinoxaline derivatives and the enthalpy of atomic oxygen in the triplet state.

Acknowledgment. Thanks are due to Fundação para a Ciência ea Tecnol ogia, F.C.T., Lisbon, Portugal, for financial support to Centro de Investigação em Química of the University of Porto (POCTI/44471/QUI/ 2002). J .R.B.G. and E.A.S. thank F.C.T. for the award of postdoctoral (SFRH/BPD/11582/2002) and Ph.D. (BD/ $5355 / 2001)$ research grants, respectively.

Supporting Information Available: Sublimation results (Tables S1-S3) and computed geometric and energetic data (Tables S4-S6). This material is available free of charge via the Internet at http://pubs.acs.org.

\section{J O035695B}

(47) Frisch, M. J .; Trucks, G. W.; Schlegel, H. B.; Scuseria, G. E.; Robb, M. A.; Cheeseman, J . R.; Zakrzewski, V. G.; Montgomery, J . A., J r.; Stratmann, R. E.; Burant, J . C.; Dapprich, S.; Millam, J. M.; Daniels, A. D.; Kudin, K. N.; Strain, M. C.; Farkas, O.; Tomasi, J .; Barone, V.; Cossi, M.; Cammi, R.; Mennucci, B.; Pomelli, C.; Adamo, C.; Clifford, S.; Ochterski, J .; Petersson, G. A.; Ayala, P. Y.; Cui, Q.; Morokuma, K.; Malick, D. K.; Rabuck, A. D.; Raghavachari, K.; Foresman, J . B.; Cioslowski, J .; Ortiz, J . V.; Stefanov, B. B.; Liu, G.; Liashenko, A.: Piskorz, P.: Komaromi, L.: Gomperts, R.: Martin, R. L.; Fox, D. J .; Keith, T.; Al-Laham, M. A.; Peng, C. Y.; Nanayakkara, A.; Gonzalez, C.; Challacombe, M.; Gill, P. M. W.; J ohnson, B. G.; Chen, W.; Wong, M. W.; Andres, J. L.; Head-Gordon, M.; Replogle, E. S.; Pople, J. A. Gaussian 98, revision A.9; Gaussian, Inc.: Pittsburgh, PA, 1998.

(48) Prosen, E. J .; Rossini, F. D. J . Res. NBS 1945, 35, 263-267. (49) Ribeiro da Silva, M. A. V.; Matos, M. A. R. J . Chem. Soc., Faraday Trans. 1995, 91, 1907-1910.

(50) Pittam, D. A.; Pilcher, G. J . Chem. Soc., Faraday Trans. 1 1972, $68,2224-2229$.

(51) Wiberg, K. B.; Waldron, R. F. J . Am. Chem. Soc. 1991, 113, $7697-7705$.

(52) Prosen, E. J .; J ohnson, W. H.; Rossini, F. D. J . Res. NBS 1946, $36,455-461$ 